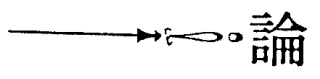

文

$539.384 .6: 539.4 .013$

開口あるいは貫通割れを有する 円筒かくの解析 ${ }^{(1)}$

一一混合要素を用いたマトリックス法による手法— 安藤良夫 ${ }^{(2)}$, 飯田国広 ${ }^{(3)}, 川$ 川忠彦 ${ }^{(4)}$ 矢川元基 ${ }^{(5)}$, 菊地文雄 ${ }^{(6)}$

本論文は Hellinger-Reissner の変分原理を一般の かく（殼）のマトリックス解析法へ応用したものであ る.朋面の要素を用いる場合にはひずみと変位の関倸 によって Novozhilov 形と Mushtari-Vlasov形の 2 種について特性マトリックスを導いた。 また平板要素 の集合としてのかくの解析についても示した. 円筒か くに対する簡単な例題については必ずしも曲面要素の ほうが精度の上で良好とはいえないようである。

応力集中に対する応用問題としてまず円孔を有する 円筒かくとだ円孔を有する円筒かくについての応力解 析を行なった. 円孔を有する円筒かくが内圧を受ける 問題については Durelli の実験とよく一致した。次に 行なった，中央に貫通割れを有する長方形曲面板の引 張りの問題では平板に対する石田の解との比較を行な ったが曲率の影響によって形状倸数がかなり大きくな ることが確かめられた。

(1) 昭 45-4-2 第 47 期通常総会粨演会において論文講演として䪙 演, 原稿受付 昭 44-10-17, 本論文は論文集 302 号（昭 46-10）に 掲载の予定. (2), (3)，(5) 正員, 東京大学工学部. (4) 正員, 東京大学生座技術研究所. (6) 准員, 東京大学工学部.

$\mathbf{5 3 9 . 3 1 3 : 5 3 9 . 3 7 1}$

非一様物質の弾性ポテンシャル論 (1)

（第 2 報，解の一意性と存在性について） 古橋 朗 蔵 ${ }^{(2)}$

前報において筆者らは，非一様物質に対する弾性ポ テンシャルの一般論を構成し，その応用として，弾性 学に現われる基本的な境界値問題が, Fredholm 形の 積分方程式を解く問題に帰着されることを示したので あるが，本論文では，これらの結果に明確な理論的根 拠を与えることを目的として，境界值問題に対する解 の一意性と存在性について考察文行なった.

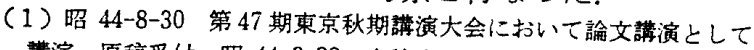

譜演, 原稿受付 昭 44-3-22, 本論文は論文集 302 号 (昭 46-10)

に揭载の予定. (2) 正員, 明治大学工学部.

678.07\%: 67z

FRP の仕事の弾性度について ${ }^{(1)}$

平井恒夫 ${ }^{(2)}$, 藤原庄一 ${ }^{(3)}$, 大槻茂寿 ${ }^{(4)}$

FRP の力学的挙動は解明への努力がなされている が，まだ十分に定説づけられていない. 本報は仕事の 弾性度を対象にして, FRP の力学的挙動を明らかにし ようとしたものである.これによると組織的な織り構 造をもつクロスを基材とする FRP に引張り力を与え た場合，仕事の弾性度はいわゆる曲りの位置で大きく 低下する。そして曲りを過ぎると再上昇するが，途中 一時的に多少の低下を示す範囲が認められる。はじめ の大きい低下は緯糸束内のき裂が原因し，つぎの小低
抄

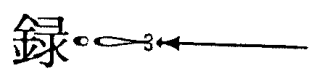

下は経米束内のき裂が原因していると思われる。これ に反して不織布を基材とする FRP の仕事の弾性度は 一方的に低下し，準均質体に近い挙動をとる。またこ 狄らのクロスの組合せ積層板は，その構成基材の種類 と量の影響をうけて，その棈成に応じた翼なる挙動を 示すことが判明した.これらのことから FRP を製作 する場合，それぞれの目的に応じた適当な檴成基材と その組合せを選ぶ必要がある。

(1) 昭 42-3-17 関西支部第 42 期定時総会講演会お上び昭 43-9-28 第 46 期全国大会講演会において䄚演，原稿受付 昭 $44-1(1-3$, 本論 文江諭文集 302 号 (昭 46-10) に揭载の予定. (2) 正員, 福井大学 工学部. (3) 正員, 大阪府立工業奖励館. (4) 正員, 閔西スレ一

\subsubsection{7: 539.388 .25}

ぜい性金属の液圧押出しにおける 表面き裂の発生(1)

（き裂発生におよぼす押出し条件の影響） 山田達夫 ${ }^{(2)}$, 阿部武治 ${ }^{(3)}$ 野口満之 $^{(4)}$, 大矢根守㖪 (5)

ぜい性金属材料の押出し加工において生ずるき裂に は,表面き裂と中心軸近傍のき裂とに分類され，材料の 種類により発生の様相を異にする. 本諭文では削者の 表面き裂（firtree crack としばしば呼ばれる）につ いて，鋳造用アルミニウム合金を用いて検討した。す なわち，まずき裂を防止するのに必要な臨界背王にお よぼす押出し比，ダイス角度，ダイス軸受部長さの影 響を調べた。またき裂発生の観察を行なうこともに， スティックスリップとき裂の関係む検討した.

その結果, 表面き裂はダイス変形域出口近傍で軸と 直角方向に発生し, 条件によってはその後斜めに伝ぱ してもみの木状の外観を呈すること，执よ゙き裂はダ イス角度の影響を受け, ダイス角度が小さいさきはき 裂の発生は比較的押出し比の小さいところで起こる ことが明らかとなった。ささらにダイス軸受部は短いほ うがき裂が発生しにくく、これは摩擦の影響を示して いる。また，実験結果にもとついてき裂発生原因に考 察が加えられた。

（1）昭 44-11-22 第 20 回望性加工連合講演会におい一詳演, 原稿受 付 昭 44-12-21, 本論文は論文集 302 号（昭 46-10）红揭载の予定. (2), (4) 准員, 京都大学工学部. (3), (5) 正員, 京都大学工

\subsection{4 .2}

\section{非線形特性支持をもつ連続はりの 静的たわみ(1)}

\section{飯 田 精 一(2)}

多数の非線形特性の支持をもつ連続はりの静的たわ み, 曲げモーメント, 支持反力などを求める計算方法 を述べた。

すべての非線形特性支持を線形ばねで置きかえて系 を線形化し，この線形化された系に対して静的たわみ の計算を行なう。この線形計算の結果から各線形ばね 定数の值を逐次仮定しなおして計算を繰返し, 非線形 支持の特性满足する解を求める。 この逐次近似計算 
1196 論文抄録

過程は一種の緩和法であるが，逐次計算安定化係数 （減速係数）を用いて解を収束させることができた。 非線形支持の例として次のものを取上げ，その特性 を述べた. (1) リグナンバイタ材の船尾管軸受の分割 片，(2）がたを有する剛支持，(3) 無負荷時にはりと 離れうるばね。

数值計算例として，非常に限られたものであるが， 上記(1)の特性を用いた船のプロペラ朝に関する計算結 果の一例を示した。

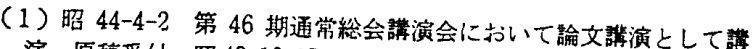

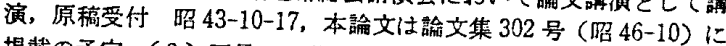
揭载の予定. (2) 正員, 三菱重工業会社神戸研究所。

534.113: 621-233

加速回転体の振動，速度特性の一考察(1)

（変加速度を有し, 減衰率 $\xi \geqq 0.1$ の場合） 松 浦 克 昌(2)

モータの駆動トルク特性に沿って駆動される加速回 転体の振動, 速度特性を駆動トルク特性の直線近似に より数值計算した.この結果，高速定常回転速度がア ンバランス量, 減衰率, 固有振動数などの振動采パラ メータにより変動することを明らかにした。また，こ れらのパラメータと定常回転速度の関倸を解析的に考 察し，定常回転速度を求好式を導いた。次に回転速 度が回転角 1 サイクル間でゆるやかに変動し，之の上 きの振動采は調和振動に近似されるという条件（数值 計算結果より減衰率 $\xi \geqq 0.1$ で近似的に成り立っこと が確認される）のもとに回転系の運動方程式立解析 し，振動により発生する動的負荷トルク学算出した。 また, 動的負荷トルク特性の計算により, 危険速度通 過の評価, 定常回転速度を図式的に求的礼ることを 示した.

(1) 昭 45-6-19 東海支部浜松地方講演会において論文隌演として

满演，原稿受付 昭45-2-3, 本綸文は論文集 302 号 (昭 46-10)

揭㦲の予定. (2) 正員, 日立製作所日立研究所.

621-52 : 681.142

$$
\text { 自動設計の一方式 (1) }
$$

\section{沖 野 教 郎(2)}

この論文の目的は自動設計に関する一方式を提案す ることにある。

現在行なわ机ている自動設計はシミュレーション形 式で試行的に進める方式が一般的であり，問題向き言 語による方法や，グラフィックシステムを用いる方法 もこれに属する.

これに対して，本論文で述べる方式は，あらかじめ 多数の標準設計用ルーチンを用意し，設計条件に忍じ てその中から適当なものを自動的に選択して適用する ことが考え方の基礎である。すなわち設計のプロセス を形式的には情報検索に置き換えうることを主張する ものである。

研究はまず設計プロセスを定式化することから出発 し，各過程を自動設計としてプログラム化する方法に ついて考察した. 特にコンピュータ主体の対話を導入 することによってこの方式の実用性に関するみとおる を得た。

論文には多数の試行的実験から導かれた一般性のあ る手順を説明し，すべり軸受の自動設計を本方式の例 題実験として報告する.

Journal of the J.S.M.E., Vol. 74 , No. 632

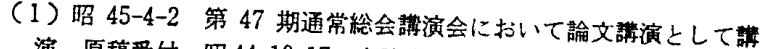
演, 原稿受付 昭 44-10-17, 本論文は論文集 302 号（昭 46-10）に 揭载の予定.（2）正員, 北海道大学工学部.

533.695.01 : 621-253 二次元減速翼列の研究 (1)

（第1街，翼列に招ける縮流効果）

生井武文 ${ }^{(2)}$, 井上雅弘 ${ }^{(3)}$, 九郎丸元雄 ${ }^{(4)}$

二次元減速翼列試験において，側壁境界層の抽気を 行なわなければ，翼列内で流れが縮流し，翼列後方の 軸流速度が増大し，流れの二次元性がここなおれ，買 列性能が劣化する。この点に関しては，すでに多くの 理論的，実験的研究がある。しかしこの問題を広範囲 の翼列の諸元に対して研究したものはなく, 翼列性能 に影響する多くの因子のうち，どの因子が流机の二次 元性に最も大きく影響するか,明らかにされていない. 本研究は側壁境界層の抽気を行なるない翼列の垁験結 果をもとにして，流れの三次元性のめやすとなる軸流 速度比に影響を及ぼす因子について検討した。軸流速 度比は，翼スパンの中央における流机のみ引けの減速 比 $\cos \beta_{1} / \cos \beta_{2}$ のみの関数で表わされる.さらに境 界畨の抽気の有無に関する翼列資料党比較検討した結 果，両者の翼列性能は，流入角が大きくなるほよ゙異な り，流入角が大きい場合には，睤列の作動領域までも 変化すること，などが明らかにされた。

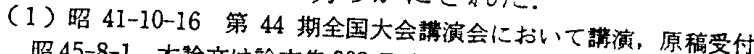

昭 45-8-1, 本論文住諭文集 302 号 (昭 46-10) に提栈の予定. (2)

(3) 九州大学工学部. (4) 准員, 九州大学工学部.

$\mathbf{5 3 3 . 6 9 5 . 0 1 : 6 2 1 - 2 5 3}$

\section{二次元減速翼列の研究 (1)}

（第 2 報，二次元翼列試験法について）

生井武文 ${ }^{(2)}$, 井上雅弘 ${ }^{(3)}$, 九郎丸元雄 ${ }^{(4)}$

減速翼列試験の資料は，一般に再現性がそしいとい われる。そこで本研究では，信頼性のある二次元翼列 資料をうるための試験方法を検討した。すなわち翼列 を形成する各翼素における流れの流入之流出の条件を 等しくする方法，および流れの二次元性を示す翼列前 後の軸流速度比を 1 にする方法を明らかにした。さら に正確な二次元翼列性能が保証される許容軸流速度比 を求めた. その結果，高流入角の翼列では，実験の技 術上二次元流れが得にくいうえに, 許容軸流速度比は 流入角が大きいほど1に近くなるこよが明らかにされ た。したがって軸流速度比を許容値以下にできない場 合の，翼列性能の修正法についても検討した。本試験 法にもとづいて NACA 65-810 翼形の高流入角領域に おける二次元翼列性能を求め, さらに回転翼列試験を 行なった結果, 本研究で提案する翼列資料の求め方が 有効であることが証明された。

(1) 昭 42-4-2 第 44 期通常総会譵演会において磷演, 原稿受付

昭 45-8-1, 本論文は踰文集 302 号 (昭 46-10) に揭载の子定. (2)

(3) 正員, 九州大学工学部. (4) 准員, 九州大学工学部.

533.695.01 : 621-253

$$
\begin{gathered}
\text { 高亜音速流における二次元 } \\
\text { タービン翼列の研究 } \\
\text { (1) }
\end{gathered}
$$

（第 1 報，翼列実験）

$$
\text { 植 西 晃(2) }
$$

本報告はホドグラフ法によって理論的に算出された 翼形の一般的な翼列性能に関する実験的研究である. 